\title{
Milk production responses to dietary stearic acid vary by production level in dairy cattle
}

\author{
P. Piantoni, A. L. Lock, and M. S. Allen ${ }^{1}$ \\ Department of Animal Science, Michigan State University, East Lansing 48824
}

\begin{abstract}
Effects of stearic acid supplementation on feed intake and metabolic and production responses of dairy cows with a wide range of milk production $(32.2$ to $64.4 \mathrm{~kg} / \mathrm{d}$ ) were evaluated in a crossover design experiment with a covariate period. Thirty-two multiparous Holstein cows (142 $\pm 55 \mathrm{~d}$ in milk) were assigned randomly within level of milk yield to treatment sequence. Treatments were diets supplemented ( $2 \%$ of diet dry matter) with stearic acid (SA; 98\% C18:0) or control (soyhulls). The diets were based on corn silage and alfalfa and contained $24.5 \%$ forage neutral detergent fiber, $25.1 \%$ starch, and $17.3 \%$ crude protein. Treatment periods were $21 \mathrm{~d}$ with the final $4 \mathrm{~d}$ used for data and sample collection. Compared with the control, SA increased dry matter intake (DMI; 26.1 vs. $25.2 \mathrm{~kg} / \mathrm{d}$ ) and milk yield (40.2 vs. 38.5 $\mathrm{kg} / \mathrm{d}$ ). Stearic acid had no effect on the concentration of milk components but increased yields of fat (1.42 vs. $1.35 \mathrm{~kg} / \mathrm{d})$, protein (1.19 vs. $1.14 \mathrm{~kg} / \mathrm{d})$, and lactose $(1.96$ vs. $1.87 \mathrm{~kg} / \mathrm{d})$. The SA treatment increased $3.5 \%$ fat-corrected milk (3.5\% FCM; 40.5 vs. $38.6 \mathrm{~kg} / \mathrm{d}$ ) but did not affect feed efficiency (3.5\% FCM/DMI, 1.55 vs. $1.53)$, body weight, or body condition score compared with the control. Linear interactions between treatment and level of milk yield during the covariate period were detected for DMI and yields of milk, fat, protein, lactose, and 3.5\% FCM; responses to SA were positively related to milk yield of cows. The SA treatment increased crude protein digestibility (67.4 vs. 65.5\%), tended to increase neutral detergent fiber digestibility (43.6 vs. $42.3 \%$ ), decreased fatty acid (FA) digestibility (56.6 vs. $76.1 \%$ ), and did not affect organic matter digestibility. Fatty acid yield response, calculated as the additional FA yield secreted in milk per unit of additional FA intake, was only $13.3 \%$ for total FA and $8.2 \%$ for C18:0 plus cis-9 C18:1. Low estimated digestibility of the SA supplement was at least partly responsible for the low FA yield response. Treatment did not affect plasma insulin, glucagon, glucose, and nonesterified FA
\end{abstract}

Received July 17, 2014.

Accepted October 22, 2014

${ }^{1}$ Corresponding author: allenm@msu.edu concentrations. Results show that stearic acid has the potential to increase DMI and yields of milk and milk components, without affecting conversion of feed to milk, body condition score, or body weight. Moreover, effects on DMI and yields of milk and milk components were more pronounced for higher-yielding cows than for lower-yielding cows.

Key words: fat supplementation, milk fat, production level, stearic acid

\section{INTRODUCTION}

Production responses to highly saturated fats $(\geq 85 \%$ saturated) have varied greatly in past experiments. Reasons for variability across experiments could be from use of different types of fat supplements, diets, and physiological states of cows. Variation in response among cows was demonstrated by Harvatine and Allen (2005) by comparing saturated and unsaturated FA supplements fed to mid-lactation cows with a wide range of milk production. In that experiment, response to treatment for yield of milk protein varied across milk yield of cows; high-producing cows responded better to the saturated FA supplement, whereas low-producing cows responded better to the unsaturated FA supplement. Moreover, Palmquist and Jenkins (1980) reported that cows with low production potential did not respond to fat supplementation compared with cows with high production potential in their feeding trials. Saturated long-chain FA often increase milk fat yield in dairy cows (Steele and Moore, 1968; Steele, 1969; Wang et al., 2010). In addition, saturated long-chain FA supplements have been shown to increase milk yield (Steele, 1969; Piantoni et al., 2013) and feed efficiency (FE; Wang et al., 2010; Lock et al., 2013; Piantoni et al., 2013) in some experiments. Interestingly, Piantoni et al. (2013) showed that a palmitic acid supplement increased milk yield, milk fat yield, and feed efficiency regardless of level of milk production.

Several studies evaluated the use of palmitic acid supplements (Mosley et al. 2007; Lock et al., 2013; Piantoni et al., 2013), but few reported the use of highly enriched stearic acid supplements. Steele and Moore (1968) evaluated a stearic acid supplement (94\% pure), fed at $\sim 4 \%$ of diet DM, on production responses for 
cows in mid-lactation; the supplement increased milk fat yield but did not affect milk fat concentration or milk yield compared with a control with no supplemental fat added. In a later study, stearic acid (85\% pure; fed at $\sim 4.25 \%$ of diet DM) increased milk yield but did not affect milk fat concentration or yield compared with a control diet with no supplemental fat added (Steele, 1969). Interestingly, and in the same experiment, the same stearic acid supplement fed at half that inclusion rate $(\sim 2.1 \%$ of diet DM) increased not only milk yield but also milk fat yield compared with the control (Steele, 1969). Even though Steele and colleagues evaluated effects of highly enriched stearic acid supplements on production of lactating cows (Steele and Moore, 1968; Steele, 1969), the cows used had low milk yield $(\sim 12 \mathrm{~kg} / \mathrm{d})$ and responses measured were related to milk yield, composition, and FA analysis only and not to DMI, digestibility, metabolic responses, or FE.

Inconsistent responses to feeding saturated fats call for additional research with pure FA sources to identify the effects of specific FA on production response of cows varying in milk yield to clarify when these supplements should be fed and their potential for increasing profitability of dairy farms. To our knowledge, no studies have evaluated the effects of a pure stearic acid supplement on digestion and metabolic and production responses in lactating dairy cows with a wide range of milk production. The objectives of this experiment were to evaluate the effects of stearic acid supplementation on digestion, metabolism, and production of lactating dairy cows and its interaction with level of milk production. Our hypothesis was that a highly pure (98\%) stearic acid supplement would increase milk yield, milk fat yield, and feed efficiency of dairy cows and that responses to treatment would differ across levels of milk production.

\section{MATERIALS AND METHODS}

\section{Animal Housing and Care}

All experimental procedures were approved by the Institutional Animal Care and Use Committee at Michigan State University (East Lansing). Each cow was housed in the same tie-stall throughout the entire experiment. Cows were fed once daily $(1000 \mathrm{~h})$ at $110 \%$ of expected intake and milked twice daily (0500 and $1600 \mathrm{~h}$ ). The amounts of feed offered and orts were weighed for each cow daily.

\section{Design and Treatment Diets}

Thirty-two multiparous Holstein cows (142 \pm 55 $\mathrm{DIM}$; mean $\pm \mathrm{SD}$ ) at the Michigan State University
Dairy Field Laboratory were used in a crossover design experiment with a covariate period. Cows were selected from the herd to provide a uniform distribution and a wide range of milk yield (32.2 to $64.4 \mathrm{~kg} / \mathrm{d}$ ). Cows were randomly assigned to treatment sequence within levels of milk production that varied by approximately $5 \mathrm{~kg} / \mathrm{d}$. The experiment was $56 \mathrm{~d}$ in duration and consisted of a 14-d preliminary (covariate) period and two 21-d treatment periods. During the preliminary period, cows were fed the control diet, and baseline values were obtained for all variables (Table 1). During the first treatment period, half of the cows $(\mathrm{n}=16)$ were fed the control diet (CONT) with no supplemental fat added, whereas the other half $(\mathrm{n}=16)$ was fed the stearic acid-supplemented diet (SA; prilled free FA supplement: 98\% C18:0; Emery Oleochemicals, Selangor, Malaysia). The stearic acid supplement was added at $2 \%$ of diet DM, replacing $2 \%$ of soyhulls in the control diet. Diets were switched for the second treatment period. The ingredient and nutrient composition of the diets fed as TMR are described in Table 2. Diets were formulated to meet requirements of the average cow in the group according to the NRC (2001).

\section{Data and Sample Collection}

Samples and data were collected during the last $4 \mathrm{~d}$ of the covariate period (d 11 to 15) and during the last $4 \mathrm{~d}$ of each treatment period (d 18 to 21). Samples of all diet ingredients $(0.5 \mathrm{~kg})$ and orts from each cow (12.5\%) were collected daily and composited by period. Milk yield was recorded, and 2 milk samples were collected at each milking. One milk sample was stored without preservative at $-20^{\circ} \mathrm{C}$ for determination of $\mathrm{FA}$ profile, and the other was stored with a preservative (Bronopol tablet; D\&F Control Systems, San Ramon, CA) added as preservative at $4^{\circ} \mathrm{C}$ for component analysis. Fecal $(500 \mathrm{~g})$ and blood samples $(\sim 15 \mathrm{~mL})$ were collected every $15 \mathrm{~h}$, resulting in 8 samples per cow per period, representing every $3 \mathrm{~h}$ of a 24 -h period to account for diurnal variation. Feces were stored in a sealed plastic cup at $-20^{\circ} \mathrm{C}$ until they were dried. Blood was collected by coccygeal venipuncture into 3 evacuated tubes; 2 contained potassium EDTA as an anticoagulant and the other contained potassium oxalate as an anticoagulant and sodium fluoride as a glycolytic inhibitor. Blood was stored on ice until centrifugation at 2,000 $\times g$ for 15 min at $4^{\circ} \mathrm{C}$ (within 30 min of sample collection). Two aliquots $(1 \mathrm{~mL})$ of plasma from the potassium EDTA tube were stored in $0.05 M$ benzamidine (final concentration) to prevent enzymatic degradation of glucagon. The remaining plasma was transferred into microcentrifuge tubes and stored at $-20^{\circ} \mathrm{C}$ until it was composited by cow by period. Body weight and BCS 
Table 1. Baseline data for cows used in this study, obtained during the preliminary period when cows were fed a common $\operatorname{diet}(\mathrm{n}=32)$

\begin{tabular}{lcccc}
\hline Parameter & Mean & SD & Minimum & Maximum \\
\hline DMI, kg/d & 28.9 & 3.11 & 22.7 & 35.4 \\
Yields, kg/d & & & & 62.5 \\
Milk & 46.1 & 9.20 & 31.9 & 2.15 \\
Fat & 1.54 & 0.29 & 1.03 & 1.94 \\
Protein & 1.41 & 0.24 & 1.03 & 3.05 \\
Lactose & 2.27 & 0.47 & 1.48 & 57.1 \\
$3.5 \%$ FCM & 44.9 & 8.07 & 31.4 & 4.38 \\
ECM & 45.0 & 7.92 & 31.8 & 4.41 \\
Milk composition, \% & & & & 6.42 \\
Fat & 3.37 & 0.47 & 2.34 & 3.72 \\
Protein & 3.08 & 0.33 & 4.63 & 3.75 \\
Lactose & 4.91 & 0.30 & 615 & 11.8 \\
BW, kg & 727 & 71.7 & 1.67 & 206 \\
BCS & 2.59 & 0.60 & 4.17 & 0.081 \\
Plasma metabolites and hormones & & & 98.4 & 228 \\
Insulin, $\mu \mathrm{IU} / \mathrm{mL}$ & 7.67 & 1.97 & 0.033 & \\
Glucagon, pg/mL & 139 & 25.5 & 50.6 & \\
Insulin:glucagon & 0.056 & 0.012 & 61.2 & \\
Glucose, mg/dL & 55.9 & 3.38 & & \\
NEFA, $\mu$ Eq/L & 95.1 & 36.5 & & \\
\hline
\end{tabular}

were recorded at the end of each period. Body condition was scored by 3 trained investigators on a 5-point scale, where $1=$ thin and $5=$ fat, as described by Wildman et al. (1982).

\section{Sample Analysis}

Feed, orts, and fecal samples were processed and analyzed for ash, NDF, indigestible NDF, CP, starch, and FA as described by Piantoni et al. (2013). Indigestible NDF was used as internal marker to calculate digestibility. Particle size of the FA supplement was determined in duplicate as described by ASAE (1997). All plasma samples were analyzed in duplicate. Commercial kits were used to determine plasma concentrations of NEFA [NEFA-HR (2) kit; Wako Chemicals USA Inc., Richmond, VA; intraassay CV: $3.2 \%$, interassay CV: 5.9\%], insulin (Coat-A-Count RIA kit; Siemens Healthcare Diagnostics, Deerfield, IL; intraassay CV: $6.0 \%$, interassay CV: $14 \%$ ), and glucagon (Glucagon RIA kit no. GL-32K; Millipore Corp., St. Charles, MA; intraassay CV: 4.4\%). Plasma glucose concentration was analyzed using a glucose oxidase method (PGO Enzyme Product No. P7119; Sigma Chemical Co., St. Louis, MO; intraassay CV: $2.3 \%$, interassay CV: $2.0 \%$ ).

Milk samples stored with preservative were analyzed for fat, true protein, lactose, MUN, and SCC by infrared spectroscopy (AOAC International, 2000), by the Michigan Herd Improvement Association (Universal Lab Services, East Lansing, MI). Milk samples stored without preservative were composited by milk fat yield and centrifuged at $17,800 \times \mathrm{g}$ for $30 \mathrm{~min}$ at $4^{\circ} \mathrm{C}$ to collect the fat, and FA composition was determined as described by Lock et al. (2013). A total of approximately 80 individual FA were quantified per sample. Even though all quantified FA were used for summation by source and concentration calculations, only select FA were included in the tables. Yield of individual FA in milk fat was calculated by correcting for glycerol content according to Schauff et al. (1992), and other milk

Table 2. Ingredient and nutrient composition of the treatment diets ${ }^{1}$

\begin{tabular}{lcc}
\hline Item & CONT & SA \\
\hline Ingredient, \% of DM & & \\
Corn silage & 35.5 & 35.5 \\
Alfalfa silage & 12.6 & 12.6 \\
Chopped alfalfa hay & 7.17 & 7.16 \\
Dry ground corn & 16.6 & 16.5 \\
Soybean meal & 15.5 & 15.5 \\
Soyhulls & 6.55 & 4.67 \\
Cottonseed with lint & 3.44 & 3.44 \\
Vitamin-mineral mix & 2.70 & 2.70 \\
Stearic acid supplement (98\% C18:0) & 0.00 & 1.92 \\
Nutrient composition & & \\
DM, \% & 55.0 & 55.1 \\
OM, \% of DM & 92.6 & 92.7 \\
NDF, \% of DM & 33.2 & 31.9 \\
\% Forage NDF & 24.5 & 24.5 \\
\% NDF from forage & 73.7 & 76.6 \\
iNDF, \% of DM & 11.5 & 11.4 \\
CP, \% of DM & 17.4 & 17.2 \\
Starch, \% of DM & 25.1 & 25.1 \\
Total FA, \% of DM & 2.73 & 4.60 \\
C18:0, \% of DM & 0.085 & 1.96
\end{tabular}

${ }^{1}$ Treatments were either control (CONT; with $2 \%$ of diet DM as added soyhulls) or a stearic acid-supplemented diet (SA; with $2 \%$ of diet DM as stearic acid; $98 \% \mathrm{C} 18: 0)$.

${ }^{2}$ Vitamin-mineral mix contained (DM basis) $34.5 \%$ sodium chloride, $29.4 \%$ calcium carbonate, $13.4 \%$ magnesium oxide, $12.5 \%$ monocalcium phosphate, $5.40 \%$ soybean oil, $4.85 \%$ trace minerals and vitamins. ${ }^{3}$ Indigestible NDF. 
lipid classes according to Glasser et al. (2007). The FA yield response (FAYR) to additional FA intake was calculated for total FA and for C18:0 plus cis-9 C18:1 with the following equation:

FAYR $(\%)=($ FA yield for SA - FA yield for $\mathrm{CONT}) /(\mathrm{FA}$ intake for SA - FA intake for CONT).

\section{Statistical Analysis}

All data were analyzed using the fit model procedure of JMP (version 9.0.2; SAS Institute Inc., Cary, NC) according to the following model:

$$
\begin{gathered}
Y_{i j k}=\mu+C_{i}+P_{j}+T_{k}+P_{j} \times T_{k}+p M Y+p M Y \\
\times T_{k}+p M Y \times p M Y+p M Y \times p M Y \times T_{k}+e_{i j k},
\end{gathered}
$$

where $Y_{i j k}=$ dependent variable, $\mu=$ overall mean, $C_{i}$ $=$ random effect of cow $(i=1$ to 32$), P_{j}=$ fixed effect of period ( $j=1$ to 2$), T_{k}=$ fixed effect of treatment ( $k=1$ to 2$), P_{j} \times T_{k}=$ interaction between period and treatment, $p M Y=$ preliminary milk yield used as covariate, $p M Y \times T_{k}=$ interaction between $p M Y$ and treatment, $p M Y \times p M Y=p M Y$ squared, $p M Y \times p M Y$ $\times T_{k}=$ interaction between $p M Y$ squared and treatment, and $e_{i j k}=$ residual error. Linear and quadratic effects for the interaction between $p M Y$ and treatment were added to evaluate responses to treatment by level of milk yield. Normality of the residuals was checked with normal probability and box plots and homogeneity of variances with plots of residuals versus predicted values. Main effects were declared significant at $P \leq$ 0.05 , and tendencies were declared at $P \leq 0.10$. Interactions were declared significant at $P \leq 0.10$, and tendencies were declared at $P \leq 0.15$. Interactions were evaluated but removed from the statistical model when not significant $(P>0.15)$. All data were expressed as least squares means and standard error of the means, unless otherwise specified.

\section{RESULTS}

\section{Production Responses}

Treatment interacted with preliminary milk yield for DMI and yields of milk, milk fat, milk protein, milk lactose, $3.5 \%$ FCM, and ECM (Table 3). Interactions indicated that responses were positively related to preliminary milk yield, and therefore, higher-producing cows responded more favorably to SA than lower-producing cows (Table 4). All interactions mentioned followed the same pattern, and the relationship between $3.5 \%$ FCM and preliminary milk yield is shown as an example in Figure 1. Overall, SA increased DMI $0.9 \mathrm{~kg} / \mathrm{d}(P=$ $0.01)$, milk yield $1.7 \mathrm{~kg} / \mathrm{d}(P=0.02), 3.5 \%$ FCM 1.9 $\mathrm{kg} / \mathrm{d}(P<0.01)$, and ECM $1.9 \mathrm{~kg} / \mathrm{d}(P<0.01)$ compared with CONT. The SA treatment did not affect the concentration of milk components but increased yields of fat $70 \mathrm{~g} / \mathrm{d}(P<0.01)$, protein $50 \mathrm{~g} / \mathrm{d}(P=0.02)$, and lactose $90 \mathrm{~g} / \mathrm{d}(P=0.02)$ and tended to decrease MUN $(P=0.08)$. The SA treatment did not affect FE $(3.5 \%$ FCM/DMI), BW, or BCS compared with CONT. Interactions were detected between preliminary milk yield and treatment for milk fat concentration (quadratic, $P$ $<0.09$ ) and BW (linear, $P<0.07$ ), but effects were small. Period-by-treatment interactions $(P \leq 0.15)$ were detected for yields of milk and milk components, indicating that period 2 was entirely responsible for the overall treatment effects (Table 5). We evaluated linear and quadratic interactions between DIM and treatment for DMI and yields of milk, 3.5\% FCM, and components to test whether there was an interaction between DIM and treatment; however, we did not detect a relationship between these responses and DIM.

\section{Total-Tract Digestibility and Plasma Metabolites and Hormones}

Treatment did not interact with preliminary milk yield to affect DM, OM, NDF, CP, or 16-carbon FA total-tract digestibility (Table 6). A tendency for a quadratic interaction between preliminary milk yield and treatment was detected for starch total-tract digestibility $(P<0.15)$; SA increased starch digestibility in high- and low-producing cows but decreased it in cows producing between 40 and $60 \mathrm{~kg}$ of milk a day compared with CONT, although differences were small.

The SA treatment did not affect DM, OM, or starch digestibility but increased CP digestibility (67.4 vs. $65.5 \%, P<0.01)$ and tended to increase NDF digestibility ( 43.6 vs. $42.3 \%, P=0.10$ ) compared with CONT. Tendencies for linear interactions between treatment and preliminary milk yield were detected for digestibility of total FA and 18-carbon FA (both $P \leq 0.15$ ), whereas SA decreased digestibility of total FA (56.6 vs. $76.1 \%, P<0.0001)$ and 18 -carbon FA (55.3 vs. $79.1 \%$, $P<0.0001)$ at all levels of milk production compared with CONT; the difference between treatments decreased as milk yield increased. The SA treatment did not affect 16-carbon FA digestibility compared with CONT. Total FA digestibility was related quadratically to total FA intake for both treatment diets (Figure 2A); digestibility of FA increased as FA intake increased up to $\sim 700 \mathrm{~g} / \mathrm{d}$ for cows fed CONT, but then it remained $\sim 80$ to $85 \%\left(\mathrm{R}^{2}=0.48 ; P=0.003\right)$. In contrast, $\mathrm{FA}$ digestibility was less than $70 \%$ for all cows when fed 
Table 3. Dry matter intake, milk production and composition, BW, and BCS for cows fed treatment diets $(\mathrm{n}=32)$

\begin{tabular}{|c|c|c|c|c|c|c|c|c|c|}
\hline Item & \multicolumn{2}{|c|}{$\operatorname{Trt}^{1}$} & SEM & \multicolumn{6}{|c|}{ Significance, $P$-value ${ }^{2}$} \\
\hline Milk & 38.5 & 40.2 & 0.70 & 0.02 & 0.13 & $<0.0001$ & 0.03 & 0.78 & 0.97 \\
\hline Fat & 1.35 & 1.42 & 0.03 & $<0.01$ & 0.08 & $<0.0001$ & 0.04 & 0.75 & 0.60 \\
\hline ECM & 38.2 & 40.1 & 0.75 & $<0.01$ & 0.07 & $<0.0001$ & 0.03 & 0.78 & 0.79 \\
\hline $\begin{array}{l}3.5 \% \mathrm{FCM} / \mathrm{DMI} \\
\text { Milk composition, } \%\end{array}$ & 1.53 & 1.55 & 0.04 & 0.25 & 0.40 & $<0.0001$ & 0.67 & 0.79 & 0.70 \\
\hline Fat & 3.60 & 3.59 & 0.12 & 0.82 & 0.44 & 0.11 & 0.22 & 0.72 & 0.09 \\
\hline Protein & 3.00 & 2.99 & 0.05 & 0.93 & 0.98 & $<0.001$ & 0.64 & 0.36 & 0.16 \\
\hline Lactose & 4.83 & 4.86 & 0.02 & 0.16 & 0.75 & 0.11 & 0.94 & 0.93 & 0.94 \\
\hline
\end{tabular}

${ }^{1}$ Trt = dietary treatment. Treatments were either control (CONT; with $2 \%$ of diet DM as added soyhulls) or a stearic acid-supplemented diet (SA; with $2 \%$ of diet DM as stearic acid; $98 \%$ C18:0).

${ }^{2} \mathrm{pMY}=$ preliminary milk yield.

SA; FA digestibility initially decreased as FA intake increased from 800 to $1,000 \mathrm{~g} / \mathrm{d}$ and then increased with FA intakes over $1,200 \mathrm{~g} / \mathrm{d}\left(\mathrm{R}^{2}=0.20 ; P=0.05\right)$. At similar total FA intakes $(\sim 900 \mathrm{~g} / \mathrm{d})$, total FA digestibility for cows in the CONT treatment was approximately 30 percentage units higher than for cows in the SA treatment. A period-by-treatment interaction was detected for 16 -carbon FA digestibility $(P=0.03)$; SA decreased 16-carbon FA digestibility during period 1 (77.4 vs. $81.9 \pm 1.55 \%)$ but increased it during period 2 (74.3 vs. $70.5 \pm 1.55 \%)$.

Preliminary milk yield interacted with treatment for intake and absorption of total FA and 18-carbon FA and tended to interact for intake and absorption of 16-carbon FA (both $P<0.05$; Table 7). Interactions indicated that differences between treatments for intakes and absorption of FA in cows with lower milk production were less than for cows with higher milk production. As expected, SA increased total FA $(1,213$ vs. $692 \mathrm{~g} / \mathrm{d}, P<0.0001)$ and 18-carbon FA (1,052 vs. $542 \mathrm{~g} / \mathrm{d}, P<0.0001)$ intakes compared with CONT. The SA treatment also increased total FA and 18-carbon FA absorbed $(P<0.0001)$. Total FA absorbed was related quadratically to total FA intake for both treatment diets, and as FA intake increased, FA absorbed increased for both diets (CONT: $\mathrm{R}^{2}=0.86, P=$ 0.01; SA: $\mathrm{R}^{2}=0.71, P=0.04$; Figure $\left.2 \mathrm{~B}\right)$. At similar total FA intakes $(\sim 900 \mathrm{~g} / \mathrm{d})$, cows in the CONT treatment absorbed $\sim 200 \mathrm{~g} / \mathrm{d}$ more $\mathrm{FA}$ than cows in the SA treatment. An interaction between treatment and period was detected for absorption of 16-carbon FA $(P$

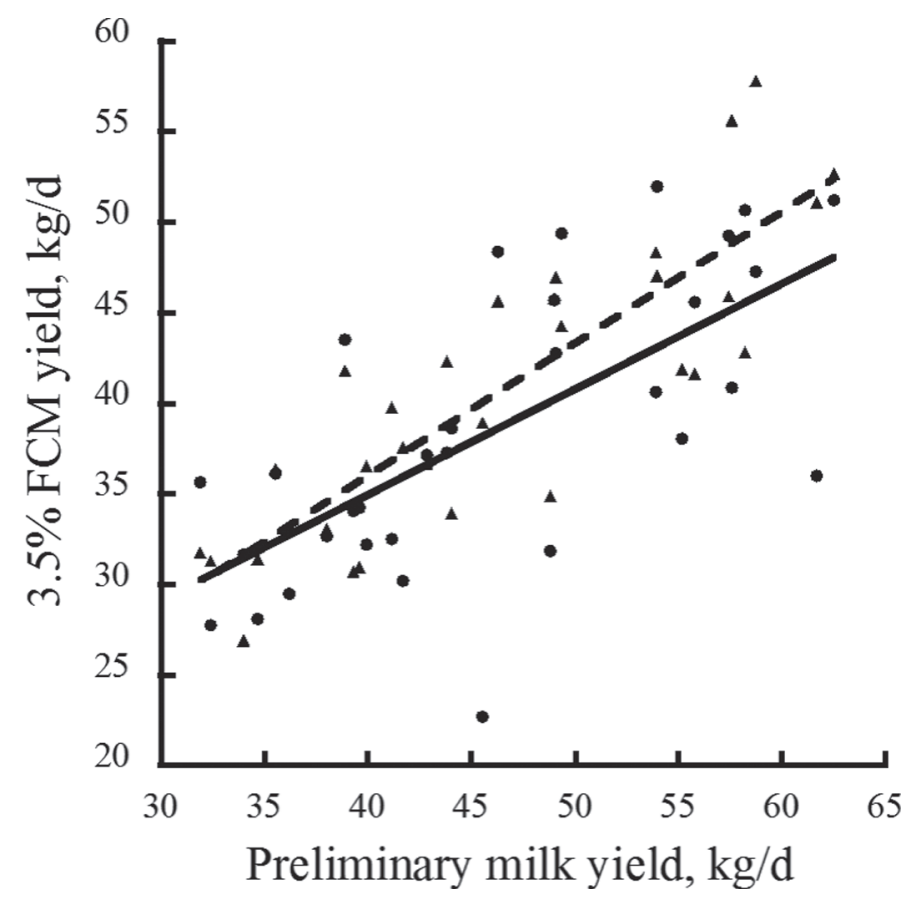

Figure 1. Relationship between $3.5 \%$ FCM and preliminary milk yield of cows fed either a control [with $2 \%$ of diet DM as added soyhulls; $\mathrm{n}=32 ; 3.5 \% \mathrm{FCM}(\mathrm{kg} / \mathrm{d})=11.7+0.582 \times \mathrm{pMY}(\mathrm{kg} / \mathrm{d}) ; \mathrm{R}^{2}=$ $0.45 ; P<0.0001$; solid line] or a stearic acid-supplemented diet [with $2 \%$ of diet DM as stearic acid; $98 \% \mathrm{C} 18: 0 ; \mathrm{n}=32 ; 3.5 \% \mathrm{FCM}(\mathrm{kg} / \mathrm{d})$ $=6.81+0.730 \times \mathrm{pMY}(\mathrm{kg} / \mathrm{d}) ; \mathrm{R}^{2}=0.73 ; P<0.0001 ;$ dashed line $]$. $\mathrm{pMY}=$ preliminary milk yield . 
Table 4. Treatment response for DMI and yields of milk and milk components for cows varying in preliminary milk yield calculated using equations of the fitted lines between response variable and preliminary milk yield by diet $(\mathrm{n}=32)$

\begin{tabular}{lccc}
\hline & \multicolumn{3}{c}{$\mathrm{pMY}, \mathrm{kg} / \mathrm{d}$} \\
\cline { 2 - 4 } Item $^{1}$ & 31.9 & 46.1 & 62.5 \\
\hline DMI $^{2} \mathrm{~kg} / \mathrm{d}$ & & & \\
CONT & 24.0 & 25.2 & 26.6 \\
SA & 24.0 & 26.1 & 28.4 \\
Yield, kg/d & & & \\
Milk & & 38.5 & 49.5 \\
CONT & 28.9 & 40.2 & 53.8 \\
SA & 28.4 & 1.36 & \\
Fat & & 1.43 & 1.65 \\
CONT & 1.10 & & \\
SA & 1.10 & 1.13 & 1.34 \\
Protein & & & \\
CONT & 0.942 & 1.19 & \\
SA & 0.937 & 38.5 & 48.1 \\
3.5\% FCM & & & \\
CONT & 30.3 & 40.5 & 52.4 \\
SA & 30.1 & & \\
\hline
\end{tabular}

${ }^{1}$ Responses to treatment diets [control (CONT, with $2 \%$ of diet DM as added soyhulls) or a stearic acid-supplemented diet (SA; with $2 \%$ of diet $\mathrm{DM}$ as stearic acid; 98\% C18:0)] were calculated using the equations of the fitted lines between response variable and preliminary milk yield ( $\mathrm{pMY})$ by $\operatorname{diet}(\mathrm{n}=32)$.

${ }^{2}$ DMI, $\mathrm{kg} / \mathrm{d}(\mathrm{CONT})=21.3+0.084 \times \mathrm{pMY}\left(\mathrm{R}^{2}=0.06 ; P=0.19\right) ;$ DMI, $\mathrm{kg} / \mathrm{d}(\mathrm{SA})=19.4+0.144 \times \mathrm{pMY}\left(\mathrm{R}^{2}=0.25 ; P<0.01\right)$.

${ }^{3}$ Milk yield, $\mathrm{kg} / \mathrm{d}(\mathrm{CONT})=7.29+0.676 \times \mathrm{pMY}\left(\mathrm{R}^{2}=0.54 ; P<\right.$ $0.0001)$; milk yield, $\mathrm{kg} / \mathrm{d}(\mathrm{SA})=1.86+0.831 \times \mathrm{pMY}\left(\mathrm{R}^{2}=0.80 ; P\right.$ $<0.0001)$.

${ }^{4}$ Milk fat yield, $\mathrm{kg} / \mathrm{d}(\mathrm{CONT})=0.527+0.018 \times \mathrm{pMY}\left(\mathrm{R}^{2}=0.32 ; P\right.$ $<0.0001)$; milk fat yield, $\mathrm{kg} / \mathrm{d}(\mathrm{SA})=0.370+0.230 \times \mathrm{pMY}\left(\mathrm{R}^{2}=\right.$ $0.56 ; P<0.0001)$.

${ }^{5}$ Milk protein yield, $\mathrm{kg} / \mathrm{d}(\mathrm{CONT})=0.527+0.013 \times \mathrm{pMY}\left(\mathrm{R}^{2}=0.35\right.$; $P<0.001)$; milk protein yield, $\mathrm{kg} / \mathrm{d}(\mathrm{SA})=0.363+0.018 \times \mathrm{pMY}\left(\mathrm{R}^{2}\right.$ $=0.62 ; P<0.0001)$.

${ }^{6} 3.5 \%$ FCM yield, $\mathrm{kg} / \mathrm{d}(\mathrm{CONT})=11.7+0.582 \times \mathrm{pMY}\left(\mathrm{R}^{2}=0.45\right.$; $P<0.0001) ; 3.5 \%$ FCM yield, $\mathrm{kg} / \mathrm{d}(\mathrm{SA})=6.81+0.730 \times \mathrm{pMY}\left(\mathrm{R}^{2}\right.$ $=0.73 ; P<0.0001)$.

$=0.05) ;$ SA decreased 16-carbon absorbed (97.4 vs. 103 $\mathrm{g} / \mathrm{d}$ ) during period 1 but increased it (81.6 vs. $72.1 \mathrm{~g} / \mathrm{d}$ ) during period 2 .

No interactions were detected between treatment and preliminary milk production for plasma metabolites and hormones measured (Table 8). Moreover, treatment did not affect plasma insulin, glucagon, glucose, or NEFA concentrations $(P>0.50)$.

\section{Milk FA Profile and Yields}

In general, no interactions were detected between treatment and preliminary milk yield for FA profile (Table 9). The SA treatment tended to decrease the concentration of FA from de novo synthesis $(P=$ $0.09)$, decreased that of mixed-source $(P<0.0001)$, but increased preformed FA concentration in milk $(P$ $<0.001)$ compared with CONT. Interactions between treatment and level of milk production indicated that high-producing cows responded more positively to SA than low-producing cows in terms of FA yields (Table 10) compared with CONT. The SA treatment increased yields of preformed FA ( 515 vs. $471 \mathrm{~g} / \mathrm{d}, P<0.0001$ ) and FA from de novo synthesis (359 vs. $344 \mathrm{~g} / \mathrm{d}, P=$ 0.03 ) in milk but did not affect yield of mixed-source FA compared with CONT. Period-by-treatment interactions were detected for the yield of several FA in milk and indicated that period 2 was responsible for the overall treatment effects.

\section{FAYR to Additional FA Intake}

Fatty acid yield response to additional FA intake was not related to preliminary milk yield when calculated for either total FA or for C18:0 plus cis-9 C18:1. For each additional 100-g intake of total FA, milk FA increased by $13.3 \mathrm{~g}$ compared with CONT. When only C18:0 plus cis-9 C18:1 were considered, for each additional 100-g intake of these FA, C18:0 plus cis-9 C18:1 increased by $8.2 \mathrm{~g}$ compared with CONT.

\section{DISCUSSION}

We conducted 3 experiments to evaluate the effects of palmitic and stearic acids on cow performance, each of which used very pure supplements $(\geq 98 \%$ pure palmitic acid, stearic acid, or both) and cows with a wide range of milk production. We chose to use cows with a wide range of milk production to evaluate whether cows of different production levels, and, therefore, physiological states, would respond differently to the same diet. Piantoni et al. (2013) compared a highly pure palmitic acid supplement (99\% C16:0) with a control diet with no supplemental fat, and Rico et al. (2014) compared the same FA supplement with a highly pure stearic acid supplement (98\% C18:0). The experiment described herein is the third of these experiments and compared the highly pure stearic acid supplement used by Rico et al. (2014) with a control diet with no supplemental fat. Milk yield measured during the covariate period was used as a covariate in all 3 experiments because this information is readily available to the producer and can be used for grouping and feeding cows.

\section{Interaction Between Stearic Acid Supplementation and Level of Production}

We previously reported that palmitic acid supplementation did not interact with level of milk production, and therefore, cows with a wide range of milk production responded similarly to treatment (Piantoni et al., 2013). However, production responses to stearic acid 
Table 5. Treatment-by-period interactions for DMI and yields of milk and milk components for cows fed treatment diets $(\mathrm{n}=32)^{1}$

\begin{tabular}{|c|c|c|c|c|c|}
\hline \multirow[b]{2}{*}{ Item } & \multicolumn{2}{|c|}{ Period 1} & \multicolumn{2}{|c|}{ Period 2} & \multirow[b]{2}{*}{ SEM } \\
\hline & CONT & SA & CONT & SA & \\
\hline DMI, kg/d & 27.1 & 27.1 & 23.3 & 25.0 & 0.59 \\
\hline \multicolumn{6}{|l|}{ Yield, kg/d } \\
\hline Milk & 42.2 & 42.0 & 34.8 & 38.5 & 1.00 \\
\hline Fat & 1.49 & 1.45 & 1.21 & 1.40 & 0.05 \\
\hline Protein & 1.24 & 1.23 & 1.04 & 1.15 & 0.03 \\
\hline Lactose & 2.05 & 2.04 & 1.68 & 1.87 & 0.05 \\
\hline $3.5 \% \mathrm{FCM}$ & 42.4 & 41.6 & 34.7 & 39.4 & 1.08 \\
\hline $\mathrm{ECM}$ & 41.9 & 41.2 & 34.5 & 38.9 & 1.06 \\
\hline
\end{tabular}

${ }^{1}$ Treatments were either control (CONT; with $2 \%$ of diet DM as added soyhulls) or a stearic acid-supplemented diet (SA; with $2 \%$ of diet DM as stearic acid; $98 \%$ C18:0).

supplementation did vary by level of milk production in the current experiment, which signifies the importance of testing pure sources of FA at different stages of lactation. To our knowledge, responses to stearic acid have not been previously reported using cows at different levels of production or high-producing cows compared with a diet with no supplemental fat. In this experiment, higher-yielding cows responded more favorably to SA than to CONT for DMI and yields of milk and milk components compared with lower-yielding cows. We were not able to discern whether the increase in DMI followed the increase in milk production or vice versa. In a recent literature review, Bionaz et al. (2013) indicated that FA can affect gene expression and more specifically gluconeogenesis. White et al. (2011) examined the effect of different FA on gene expression of rat hepatoma cells transfected with specific bovine promoters and showed that stearic acid decreased expression of pyruvate carboxylase, a key gluconeogenic enzyme. Even though results from that experiment suggest stearic acid would decrease milk yield through a decrease in gluconeogenesis, which is opposite to what we observed in the current experiment, a potential effect of stearic acid on gene expression at the level of the mammary gland or liver cannot be ruled out.

Because one of the objectives of this study was to evaluate linear or quadratic relationships between preliminary milk yield (measured during the covariate period) and treatment, cows with a wide range and uniform distribution of milk yield were selected from the herd so there were no distinct groups (e.g., highand low-milk-yield groups) to compare statistically. However, we calculated the response to CONT and SA for cows using the minimum, mean, and maximum preliminary milk yield (Table $1 ; 31.9,46.1$, and 62.5 $\mathrm{kg} / \mathrm{d}$ ) using the equations of the fitted lines between response variable and preliminary milk yield by diet (see Figure 1). Compared with CONT, SA increased DMI and yields of milk, milk fat and protein, and $3.5 \% \mathrm{FCM}$ for cows producing 62.5 and $46.1 \mathrm{~kg} / \mathrm{d}$. In contrast, SA did not affect DMI and yields of milk, milk fat and protein, and $3.5 \% \mathrm{FCM}$ for cows producing $31.9 \mathrm{~kg} / \mathrm{d}$, compared with CONT (Table 4).

Interactions between treatment and preliminary milk yield that were not discussed were small and likely not biologically meaningful. In addition, we reported

Table 6. Total-tract digestibility of nutrients for cows fed treatment diets $(\mathrm{n}=32)$

\begin{tabular}{|c|c|c|c|c|c|c|c|c|c|}
\hline Item, \% & \multicolumn{2}{|c|}{$\operatorname{Trt}^{1}$} & SEM & \multicolumn{6}{|c|}{ Significance, $P$-value ${ }^{2}$} \\
\hline $\mathrm{OM}$ & 65.3 & 65.9 & 0.43 & 0.22 & 0.38 & 0.34 & 0.56 & 0.38 & 0.86 \\
\hline NDF & 42.3 & 43.6 & 0.66 & 0.10 & 0.97 & 0.85 & 0.86 & 0.23 & 0.78 \\
\hline $\mathrm{CP}$ & 65.5 & 67.4 & 0.62 & $<0.01$ & 0.35 & 0.12 & 0.30 & 0.88 & 0.72 \\
\hline 16-C FA & 76.2 & 75.9 & 1.10 & 0.79 & 0.03 & 0.07 & 0.28 & 0.63 & 0.86 \\
\hline 18-C FA & 79.1 & 55.3 & 1.54 & $<0.0001$ & 0.32 & 0.26 & 0.15 & 0.45 & 0.83 \\
\hline
\end{tabular}

${ }^{1}$ Trt $=$ dietary treatment. Treatments were either control (CONT; with $2 \%$ of diet DM as added soyhulls) or a stearic acid-supplemented diet (SA; with $2 \%$ of diet DM as stearic acid; $98 \%$ C18:0).

${ }^{2} \mathrm{pMY}=$ preliminary milk yield. 
Table 7. Total FA intake and FA absorbed for cows fed treatment diets $(\mathrm{n}=32)$

\begin{tabular}{|c|c|c|c|c|c|c|c|}
\hline \multirow[b]{2}{*}{ Item } & \multicolumn{2}{|c|}{$\operatorname{Trt}^{1}$} & \multirow[b]{2}{*}{ SEM } & \multicolumn{4}{|c|}{ Significance, $P$-value ${ }^{2}$} \\
\hline & CONT & SA & & Trt & Trt $\times$ period & $\mathrm{pMY}$ & $\mathrm{pMY} \times \operatorname{Trt}$ \\
\hline Total FA intake, $\mathrm{g} / \mathrm{d}$ & 692 & 1,213 & 15.1 & $<0.0001$ & 0.82 & 0.01 & $<0.01$ \\
\hline 16-C intake & 114 & 118 & 1.88 & $<0.01$ & 0.27 & 0.01 & 0.14 \\
\hline 18-C intake & 542 & 1,052 & 12.8 & $<0.0001$ & 0.65 & 0.01 & $<0.01$ \\
\hline Total FA absorbed, g/d & 534 & 689 & 15.4 & $<0.0001$ & 0.72 & 0.29 & 0.02 \\
\hline 16-C FA absorbed & 87.4 & 89.5 & 1.98 & 0.21 & 0.05 & 0.30 & 0.12 \\
\hline 18-C FA absorbed & 435 & 584 & 13.0 & $<0.0001$ & 1.00 & 0.26 & 0.02 \\
\hline
\end{tabular}

${ }^{1}$ Trt $=$ dietary treatment. Treatments were either control (CONT; with $2 \%$ of diet DM as added soyhulls) or a stearic acid-supplemented diet (SA; with $2 \%$ of diet DM as stearic acid; $98 \%$ C18:0).

${ }^{2} \mathrm{pMY}=$ preliminary milk yield.

interactions that were significant or tended to be significant between treatment and period for several responses measured, including yields of milk and milk components. Unfortunately, we could not determine the reasons for these interactions. However, interactions between period and treatment were detected only when preliminary milk yield was included in the model as a covariate; when preliminary milk yield and its interactions were removed from the model, interactions between period and treatment were not significant $(P$ $>0.15)$.

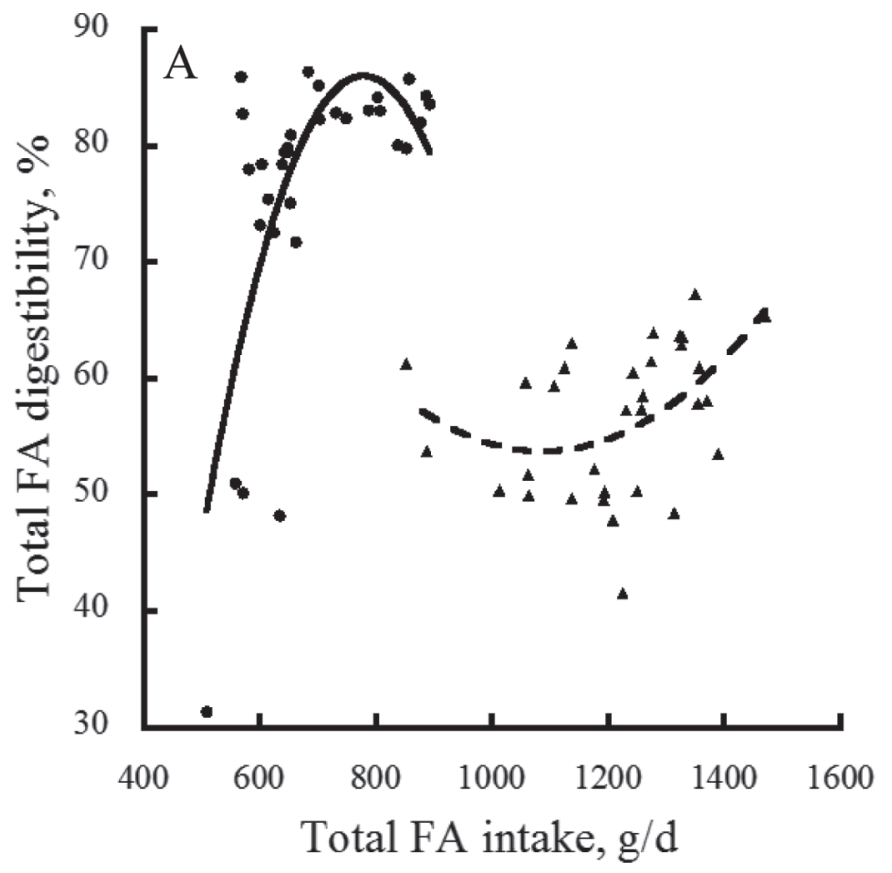

\section{Production Responses to Stearic Acid Supplementation}

Overall, SA increased milk yield and milk fat yield, which is in agreement with previous findings reported by Steele (1969), who fed a stearic acid supplement ( $85 \%$ pure) at $\sim 2.1 \%$ of diet DM and showed that stearic acid not only increased milk yield by $1.2 \mathrm{~kg} / \mathrm{d}$, but also milk fat yield by $41 \mathrm{~g} / \mathrm{d}$ compared with a control diet with no supplemental fat. However, Steele (1969) used low-producing cows $(\sim 12 \mathrm{~kg} / \mathrm{d})$, and considering

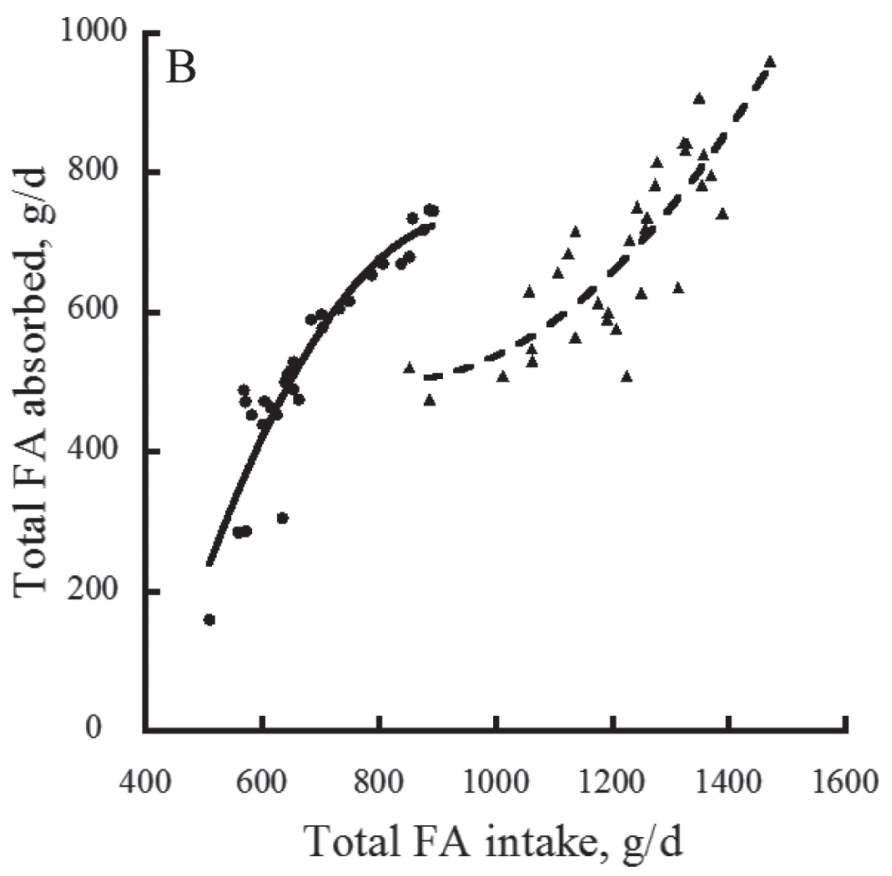

Figure 2. (A) Relationship between total FA digestibility and total FA intake of cows fed either a control $\{$ with $2 \%$ of diet DM as added soyhulls; $\mathrm{n}=32$; total FA digestibility $(\%)=240-0.178 \times$ total FA intake $(\mathrm{g} / \mathrm{d})-0.0005 \times[\text { total FA intake }(\mathrm{g} / \mathrm{d})-952]^{2} ; \mathrm{R}^{2}=0.48 ; P=$ 0.003; solid line $\}$ or a stearic acid-supplemented diet $\{$ with $2 \%$ of diet DM as stearic acid; $98 \%$ C18:0; $\mathrm{n}=32$; total FA digestibility $(\%)=76.1$ $-0.022 \times$ total FA intake $(\mathrm{g} / \mathrm{d})-0.00008 \times[\text { total FA intake }(\mathrm{g} / \mathrm{d})-952]^{2} ; \mathrm{R}^{2}=0.20 ; P=0.05$; dashed line . (B) Relationship between total FA absorbed and total FA intake of cows fed either a control $\{\mathrm{n}=32$; total FA absorbed $(\mathrm{g} / \mathrm{d})=738-0.005 \times$ total FA intake $(\mathrm{g} / \mathrm{d})-0.003$ $\times[\text { total FA intake }(\mathrm{g} / \mathrm{d})-952]^{2} ; \mathrm{R}^{2}=0.86 ; P=0.01 ;$ solid line $\}$ or a stearic acid-supplemented diet $\{\mathrm{n}=32 ;$ total FA absorbed $(\mathrm{g} / \mathrm{d})=240$ $-0.295 \times$ total FA intake $(\mathrm{g} / \mathrm{d})-0.001 \times[\text { total FA intake }(\mathrm{g} / \mathrm{d})-952]^{2} ; \mathrm{R}^{2}=0.71 ; P=0.04 ;$ dashed line $)$. 
Table 8. Plasma metabolites and hormones of cows fed treatment diets $(\mathrm{n}=32)$

\begin{tabular}{|c|c|c|c|c|c|}
\hline \multirow[b]{2}{*}{ Item } & \multicolumn{2}{|c|}{$\operatorname{Trt}^{1}$} & \multirow[b]{2}{*}{ SEM } & \multicolumn{2}{|c|}{ Significance, $P$-value } \\
\hline & CONT & $\mathrm{SA}$ & & Trt & Trt $\times$ period \\
\hline Insulin, $\mu \mathrm{IU} / \mathrm{mL}$ & 8.62 & 8.66 & 0.39 & 0.89 & 0.75 \\
\hline Glucagon, pg/mL & 141 & 141 & 4.81 & 0.72 & 0.36 \\
\hline Insulin:glucagon & 0.062 & 0.063 & 0.003 & 0.57 & 0.32 \\
\hline Glucose, $\mathrm{mg} / \mathrm{dL}$ & 56.1 & 55.8 & 0.52 & 0.51 & 0.65 \\
\hline NEFA, $\mu \mathrm{Eq} / \mathrm{L}$ & 83.7 & 85.3 & 3.02 & 0.51 & 0.65 \\
\hline
\end{tabular}

${ }^{1}$ Trt = dietary treatment. Treatments were either control (CONT; with $2 \%$ of diet DM as added soyhulls) or a stearic acid-supplemented diet (SA; with $2 \%$ of diet DM as stearic acid; $98 \%$ C18:0).

the interaction with level of production reported in the current experiment, we would not have expected a positive result in those cows. In contrast and consistent with our results, duodenal infusions of stearic acid (92.3\% pure) did not affect milk production or total FA concentration in milk in cows producing less than $30 \mathrm{~kg}$ of milk daily (Enjalbert et al., 2000).

The SA treatment also increased DMI and 3.5\% FCM but did not affect FE or BCS in the current experiment. Rabiee et al. (2012) conducted a meta-analysis of treatment means from the literature and concluded that fat feeding can improve FE through decreased DMI and increased milk yield and milk fat yield. However, in that meta-analysis, FE was not calculated separately for each study, which could have altered the conclusion reached. Nevertheless, and in agreement with Rabiee et al. (2012), several experiments have reported an increase in FE when long-chain saturated FA sources were fed to dairy cows (Wang et al., 2010; Lock et al., 2013; Piantoni et al., 2013). Lack of treatment effect on BCS observed in this experiment is consistent with the lack of treatment effects on metabolic and hormonal profiles. Effects of supplemental saturated FA on metabolic response have been inconsistent and are likely dependent upon physiological state of cows and FA supplement (Harvatine and Allen, 2006).

Stearic acid increased DMI in the current experiment, and DMI response increased with milk yield of cows. Consistent with our findings, Mosley et al. (2007) showed that a palmitic acid supplement ( $>85 \%$ pure)

Table 9. Milk FA concentrations ${ }^{1}$ of cows fed treatment diets $(\mathrm{n}=32)$

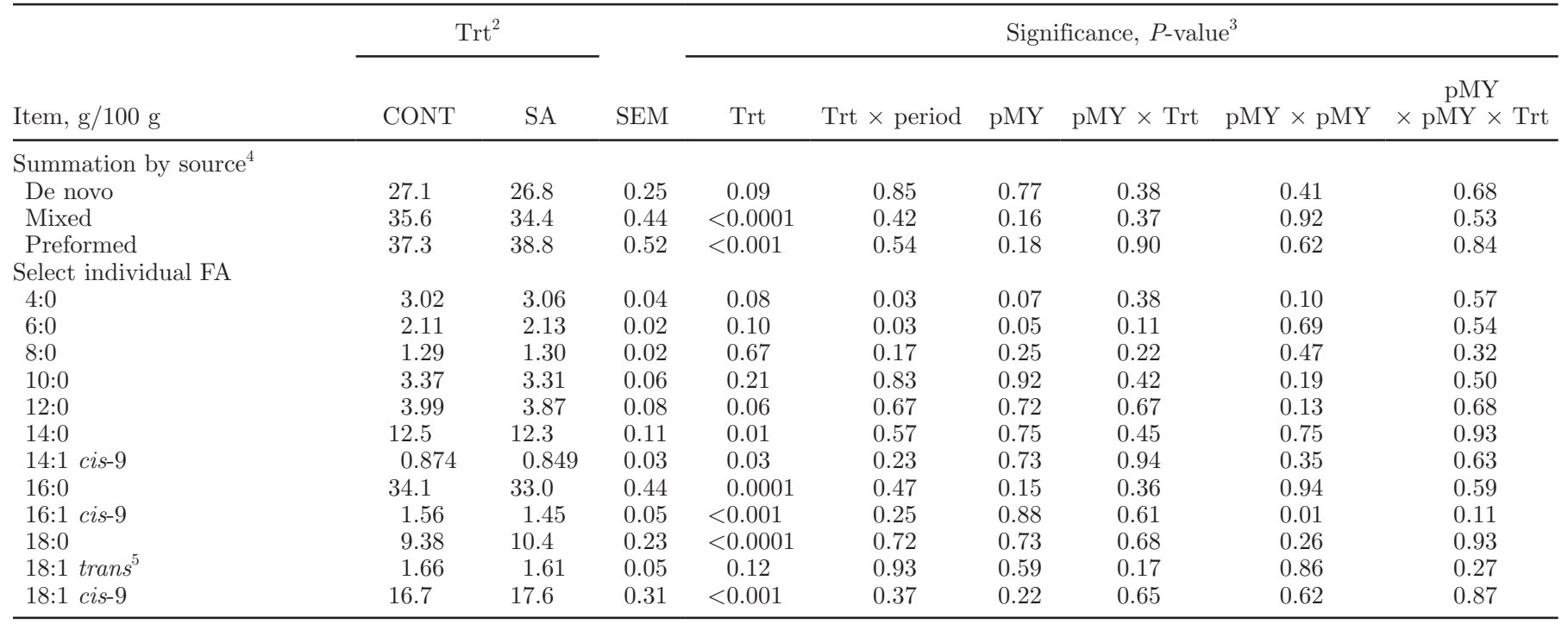

${ }^{1}$ A total of approximately 80 individual FA were quantified and used for calculations (summation by source and concentrations). Only select FA are reported in the table.

${ }^{2}$ Trt $=$ dietary treatment. Treatments were either control (CONT; with $2 \%$ of diet DM as added soyhulls) or a stearic acid-supplemented diet (SA; with $2 \%$ of diet DM as stearic acid; $98 \%$ C18:0).

${ }^{3} \mathrm{pMY}=$ preliminary milk yield.

${ }^{4}$ De novo FA originate from mammary de novo synthesis ( $<16$ carbons), preformed FA originate from dietary or mobilized FA extracted from plasma (>16 carbons), and mixed FA originate from both sources (C16:0 plus cis-9 C16:1; Bauman and Griinari, 2003).

${ }^{5}$ Total 18:1 trans FA. 
Table 10. Milk FA yield ${ }^{1}$ of cows fed treatment diets $(\mathrm{n}=32)$

\begin{tabular}{|c|c|c|c|c|c|c|c|c|c|}
\hline Item, g/d & \multicolumn{2}{|c|}{$\operatorname{Trt}^{2}$} & SEM & \multicolumn{6}{|c|}{ Significance, $P$-value ${ }^{3}$} \\
\hline De novo & 344 & 359 & 9.55 & 0.03 & 0.07 & $<0.0001$ & 0.04 & 0.58 & 0.87 \\
\hline Mixed & 451 & 461 & 13.8 & 0.14 & 0.22 & $<0.0001$ & 0.12 & 0.77 & 0.43 \\
\hline Preformed & 471 & 515 & 12.1 & $<0.0001$ & 0.07 & $<0.0001$ & 0.05 & 0.93 & 0.63 \\
\hline $6: 0$ & 26.9 & 28.7 & 0.83 & $<0.01$ & 0.03 & $<0.0001$ & 0.02 & 0.94 & 0.59 \\
\hline $8: 0$ & 16.5 & 17.5 & 0.53 & $<0.01$ & 0.05 & $<0.0001$ & 0.03 & 0.59 & 0.91 \\
\hline 10:0 & 42.7 & 44.5 & 1.51 & 0.07 & 0.13 & $<0.001$ & 0.07 & 0.34 & 0.87 \\
\hline $12: 0$ & 50.4 & 51.9 & 1.75 & 0.20 & 0.20 & 0.001 & 0.15 & 0.27 & 0.79 \\
\hline $14: 0$ & 158 & 164 & 4.10 & 0.03 & 0.10 & $<0.0001$ & 0.04 & 0.69 & 0.79 \\
\hline $14: 1$ cis-9 & 10.9 & 11.3 & 0.50 & 0.14 & 0.86 & $<0.01$ & 0.27 & 0.30 & 0.67 \\
\hline $16: 0$ & 433 & 443 & 13.3 & 0.13 & 0.22 & $<0.0001$ & 0.12 & 0.83 & 0.44 \\
\hline
\end{tabular}

${ }^{1}$ A total of approximately 80 individual FA were quantified and used for calculations (summation by source). Only select FA are reported in the table.

${ }^{2}$ Trt $=$ dietary treatments. Treatments were either control (CONT; with $2 \%$ of diet DM as added soyhulls) or a stearic acid-supplemented diet (SA; with $2 \%$ of diet DM as stearic acid; $98 \%$ C18:0).

${ }^{3} \mathrm{pMY}=$ preliminary milk yield.

${ }^{4}$ De novo FA originate from mammary de novo synthesis ( $<16$ carbons), preformed FA originate from dietary or mobilized FA extracted from plasma ( $>16$ carbons), and mixed FA originate from both sources (C16:0 plus cis-9 C16:1) (Bauman and Griinari, 2003).

${ }^{5}$ Total 18:1 trans FA.

fed at $500 \mathrm{~g} / \mathrm{d}$ increased DMI by $3.1 \mathrm{~kg} / \mathrm{d}$ compared with a control diet with no supplemental fat. A statistical analysis of treatment means from the literature indicated that saturated FA supplements had little or no effect on DMI, but none of the supplements evaluated were pure stearic or palmitic acid supplements (Allen, 2000). Consistent with this, our companion studies reported that a highly pure source of palmitic acid did not affect DMI compared with a control diet with no supplemental fat (Piantoni et al., 2013) or with stearic acid (Rico et al., 2014). Moreover, FA supplements did not interact with preliminary milk yield to affect DMI in either experiment. Different DMI responses within the set of experiments might be related to the different FA (palmitic or stearic) and diets fed; experiments were done in different years and forage NDF of the diets reported by Piantoni et al. (2013) and Rico et al. (2014) was $19.1 \%$, which is 5.4 percentage units lower than the one reported in this experiment. Diets for all 3 experiments were formulated to contain $30 \% \mathrm{NDF}$, but diets fed in this experiment resulted in slightly higher NDF concentrations.

\section{FAYR and Digestibility of Nutrients}

We calculated FAYR to evaluate the efficiency of utilization of the stearic acid supplement for milk fat yield. In agreement with Enjalbert et al. (2000), we observed a lower FAYR to additional dietary stearic acid, compared with additional dietary palmitic acid (Piantoni et al., 2013). Enjalbert et al. (2000) reported an apparent FAYR of $46.7 \%$ for palmitic acid and $12.0 \%$ for stearic acid, both infused in the duodenum, whereas we reported a FAYR of $16.6 \%$ for palmitic acid (Piantoni et al., 2013) and $8.2 \%$ for stearic acid in this study. Other experiments that calculated FAYR to palmitic acid supplementation also reported lower FAYR than that of Enjalbert et al. (2000): Lock et al. (2013) reported a FAYR of $29.7 \%$ and Warntjes et al. (2008) reported a FAYR of $16.5 \%$ in a field study. The 18-carbon FAYR of $8.2 \%$ in this experiment was approximately one-half of that reported for 16-carbon FA in Piantoni et al. (2013), and the difference observed is likely because of the digestibility and tissue availability of the FA and to the different prill size of the FA supplements fed; the prill size of the palmitic acid supplement was smaller and more uniform than that of the stearic acid supplement $[0.89 \pm 0.14$ vs. $0.98 \pm$ $0.39 \mathrm{~mm}$ (mean $\pm \mathrm{SD})]$, which could have affected absorption of the FA. The calculated digestibility for the palmitic acid supplement used by Piantoni et al. (2013) was $48.1 \%$, whereas the calculated digestibility for the stearic acid used in this experiment was only $28.4 \%$. However, transfer of absorbed 18-carbon FA into milk was also low, so a large proportion of the stearic acid absorbed was likely oxidized by extra-hepatic tissues 
decreasing its export in milk but sparing other fuels for milk synthesis.

Organic-matter digestibility was not altered by treatment diets, which is consistent with previous experiments and the notion that saturated FA supplements are inert in the rumen (Grummer, 1988; Schauff and Clark, 1989). The SA treatment not only did not affect OM digestibility but also tended to increase NDF digestibility. Saturated fats can increase digestibility of nutrients (Piantoni et al., 2013), and this might be from release of cholecystokinin from the duodenum (Choi et al., 2000), which can reduce gut motility and increase ruminal retention time. Piantoni et al. (2013) showed that a palmitic acid supplement increased total-tract NDF digestibility (39.0 vs. $35.7 \% ; P<0.001$ ) compared with a control diet with no supplemental fat, and this increase might be at least partially explained by the observed increase in plasma cholecystokinin concentration. In contrast, SA decreased total FA and 18-carbon FA digestibility in the current experiment. The overall decrease in FA digestibility was expected because it has been previously shown that increased FA intake is related to decreased FA digestibility (Palmquist, 1991; Piantoni et al., 2013). However, we did not expect SA would decrease total FA digestibility so markedly (56.6 vs. $76.1 \%$ ). Interestingly, cows in the CONT diet with lower total FA intakes showed great variation in total FA digestibility (from 31 to $86 \%$ ), and total FA intake and digestibility were positively related at lower intakes of total FA but negatively related at higher intakes of total FA for cows in CONT (Figure 2). In addition, variation in total FA digestibility from cows in the SA diet was not very well explained by total FA intake $\left(\mathrm{R}^{2}\right.$ $=0.20$ ), but total FA digestibility and intake were positively correlated. Interactions between preliminary milk yield and treatment for intake and absorption of total and 18-carbon FA followed the DMI response pattern, and therefore, cows with higher milk production had higher intake and absorption of total and 18-carbon FA compared with cows with lower milk production when fed SA compared with CONT. Total FA absorbed increased as total FA intake increased for both CONT and SA cows. In agreement with others (Palmquist, 1991; Piantoni et al., 2013), total FA absorbed increased at a slower rate as total FA intake increased for cows in the CONT treatment. In contrast, total FA absorbed increased at a faster rate as total FA intake increased for cows receiving the SA treatment.

\section{Milk FA}

As expected, the SA treatment increased the yield of preformed FA in milk, mainly composed of stearic acid and other 18-carbon FA varying in their degree of saturation, consistent with increased supply of preformed FA (Steele and Moore, 1968; Enjalbert et al., 2000). In addition, the interaction between preliminary milk yield and treatment detected for yield of milk FA followed the same pattern as DMI and milk yield response, so it was related to the effect of SA on intake and milk yield. Although we expected SA to increase preformed FA in milk, the increase in FA from de novo synthesis was not expected (Grummer, 1991; Enjalbert et al., 2000). Fatty acids of different carbon chain lengths appear to have preferences in positional distributions, with C18:0 usually found at the first carbon of triglycerides, whereas C18:1 is either found in the first or third carbon and de novo FA in carbons second and third (Parodi, 1983). The increase in short-chain FA might help maintain fluidity of milk when long-chain FA in milk increase (Barbano and Sherbon, 1980).

\section{CONCLUSIONS}

Stearic acid has the potential to increase DMI and yields of milk and milk components, without affecting $\mathrm{FE}, \mathrm{BCS}$, or BW. Moreover, stearic acid increased DMI and yields of milk and milk components more as milk yield of cows increased. Reasons why higheryielding cows responded more positively to stearic acid supplementation than lower-yielding cows could not be determined in this study. The low FAYR to stearic acid supplementation was a result of the low digestibility of the supplement and low apparent uptake of stearic acid by the mammary gland. To evaluate the potential use of a stearic acid supplement on farms, producers need to calculate the marginal economic return of the supplement, considering not only the increase in yields of milk and milk solids, but also the increase in DMI observed and the group of cows to which this supplement is to be fed.

\section{ACKNOWLEDGMENTS}

We acknowledge the Malaysian Palm Oil Board (Selangor, Malaysia) for financial support of this research and T. Tompkins and Milk Specialties Global for supplying the stearic acid supplement. We also thank D. G. Main, R. A. Longuski, C. L. Preseault, S. E. Stocks, W. Brown, R. E. Kreft (all from Michigan State University) and the staff of the Michigan State University Dairy Cattle Field Laboratory (East Lansing) for their assistance in this experiment.

\section{REFERENCES}

Allen, M. S. 2000. Effects of diet on short-term regulation of feed intake by lactating dairy cattle. J. Dairy Sci. 83:1598-1624.

AOAC International. 2000. Official Methods of Analysis. 17th ed. AOAC Int., Arlington, VA. 
ASAE (American Society of Agricultural Engineers). 1997. Method for determining and expressing fineness of feed materials by sieving. ASAE Standard ASAE S319.3.

Barbano, D. M., and J. W. Sherbon. 1980. Polyunsaturated protected lipid: Effect on triglyceride molecular weight distribution. J. Dairy Sci. 63:731-740.

Bauman, D. E., and J. M. Griinari. 2003. Nutritional regulation of milk fat synthesis. Annu. Rev. Nutr. 23:203-227.

Bionaz, M., S. Chen, M. J. Khan, and J. J. Loor. 2013. Functional role of PPARs in ruminants: Potential targets for fine-tuning metabolism during growth and lactation. PPAR Res. 2013: 684159

Choi, B. R., D. Palmquist, and M. Allen. 2000. Cholecystokinin mediates depression of feed intake in dairy cattle fed high fat diets. Domest. Anim. Endocrinol. 19:159-175.

Enjalbert, F., M. C. Nicot, C. Bayourthe, and R. Moncoulon. 2000 Effects of duodenal infusions of palmitic, stearic, or oleic acids on milk composition and physical properties of butter. J. Dairy Sci. 83:1428-1433.

Glasser, F., M. Doreau, A. Ferlay, and Y. Chilliard. 2007. Technical note: Estimation of milk fatty acid yield from milk fat data. J. Dairy Sci. 90:2302-2304.

Grummer, R. R. 1988. Influence of prilled fat and calcium salt of palm oil fatty acids on ruminal fermentation and nutrient digestibility. J. Dairy Sci. 71:117-123.

Grummer, R. R. 1991. Effect of feed on composition of milk fat. J. Dairy Sci. 74:3244-3257

Harvatine, K. J., and M. S. Allen. 2005. The effect of production level on feed intake, milk yield, and endocrine responses to two fatty acid supplements in lactating cows. J. Dairy Sci. 88:4018-4027.

Harvatine, K. J., and M. S. Allen. 2006. Effects of fatty acid supplements on milk yield and energy balance of lactating dairy cows. J Dairy Sci. 89:1081-1091.

Lock, A. L., C. L. Preseault, J. E. Rico, K. E. DeLand, and M. S. Allen. 2013. Feeding a C16:0-enriched fat supplement increased the yield of milk fat and improved feed efficiency. J. Dairy Sci. 96:6650-6659.

Mosley, S. A., E. E. Mosley, B. Hatch, J. I. Szasz, A. Corato, N. Zacharias, D. Howes, and M. A. McGuire. 2007. Effect of varying levels of fatty acids from palm oil on feed intake and milk production in Holstein cows. J. Dairy Sci. 90:987-993.

NRC. 2001. Nutrient Requirements of Dairy Cattle. 7th rev. ed. Natl. Acad. Sci., Washington, DC.

Palmquist, D. L. 1991. Influence of source and amount of dietary fat on digestibility in lactating cows. J. Dairy Sci. 74:1354-1360.
Palmquist, D. L., and T. Jenkins. 1980. Fat in lactation rations: Review . J. Dairy Sci. 63:1-14.

Parodi, P. W. 1983. Positional distribution of fatty acids in triglycerides from prepartum mammary gland secretion and early postpartum milk. J. Dairy Sci. 66:912-919.

Piantoni, P., A. L. Lock, and M. S. Allen. 2013. Palmitic acid increased yields of milk and milk fat and nutrient digestibility across production level of lactating cows. J. Dairy Sci. 96:7143-7154.

Rabiee, A. R., K. Breinhild, W. Scott, H. M. Golder, E. Block, and I. J. Lean. 2012. Effect of fat additions to diets of dairy cattle on milk production and components: A meta-analysis and metaregression. J. Dairy Sci. 95:3225-3247.

Rico, J. E., M. S. Allen, and A. L. Lock. 2014. Compared with stearic acid, palmitic acid increased the yield of milk fat and improved feed efficiency across production level of cows. J. Dairy Sci. 97:1057-1066

Schauff, D. J., and J. H. Clark. 1989. Effects of prilled fatty acids and calcium salts of fatty acids on rumen fermentation, nutrient digestibilities, milk production, and milk composition. J. Dairy Sci. 72:917-927.

Schauff, D. J., J. P. Elliott, J. H. Clark, and J. K. Drackley. 1992. Effects of feeding lactating dairy cows diets containing whole soybeans and tallow. J. Dairy Sci. 75:1923-1935.

Steele, W. 1969. The effects of dietary palmitic and stearic acids on milk yield and composition in the cow. J. Dairy Res. 36:369-373.

Steele, W., and J. H. Moore. 1968. The effects of a series of saturated fatty acids in the diet on milk-fat secretion in the cow. J. Dairy Res. 35:361-370.

Wang, J. P., D. Bu, J. Wang, X. Huo, and T. Guo. 2010. Effect of saturated fatty acid supplementation on production and metabolism indices in heat-stressed mid-lactation dairy cows. J. Dairy Sci. 93:4121-4127.

Warntjes, J., P. Robinson, E. Galo, E. DePeters, and D. Howes. 2008. Effects of feeding supplemental palmitic acid (C16:0) on performance and milk fatty acid profile of lactating dairy cows under summer heat. Anim. Feed Sci. Technol. 140:241-257.

White, H. M., S. L. Koser, and S. S. Donkin. 2011. Differential regulation of bovine pyruvate carboxylase promoters by fatty acids and peroxisome proliferator-activated receptor- $\alpha$ agonist. J. Dairy Sci. 94:3428-3436.

Wildman, E. E., G. M. Jones, P. E. Wagner, R. L. Boman, H. F. Troutt Jr., and T. N. Lesch. 1982. A dairy cow body condition scoring system and its relationship to selected production characteristics. J. Dairy Sci. 65:495-501. 